\title{
The Effect of Work Motivation and Professional Competence of Teachers on the Success of Junior High School Teachers
}

\author{
Nita Fitriani ${ }^{1 *}$, Nur Ahyani $^{2}$, Nila Kesumawati ${ }^{2}$ \\ ${ }^{1}$ SMP Negeri 15 OKU \\ ${ }^{2}$ Universitas PGRI Palembang \\ *Corresponding author. Email: nitasmp15@gmail.com
}

\begin{abstract}
The purpose of this study was to determine and describe the effect of work motivation and professional competence of teachers on the performance of junior high school teachers in Kedaton subdistrict, observation highway, Ogan Komering Ulu Regency. The research population of junior high school teachers in Kedaton Peninajian Raya Subdistrict, Ogan Komering Ulu Regency is 100 teachers. The sampling technique was simple random sampling with a total of 50 teachers. The data collection method used a questionnaire. The results show 1) there is a significant effect of work motivation on teacher performance, 2) there is a significant effect of teacher professional competence on teacher performance, 3) there is a significant influence between work motivation and teacher professional competence on teacher performance.
\end{abstract}

Keywords: Work motivation, Teacher professional competence, Teacher performance.

\section{INTRODUCTION}

The background of this research begins with the results of pre-observations carried out on 20 March 2020 at the SMP kecamatan Kedaton Observation Raya regency Ogan Komering Ulu which was found that there are still some problems in the field including there are still some teachers who are less disciplined by arriving late to school, starting and ending inappropriate learning. time, learning administration is structured that does not follow standard processes (Permendikbud no 22 of 2016), class management is not optimal, learning is boring because there is no innovation in learning, and a lack of desire for self-development, such as participating in the Subject Teacher Conference (MGMP) or training self-development.

This problem can have an impact on education in Indonesia where in Law Number 20 of 2003 Article 1 paragraph 1 concerning the National Education System states that: Education is a conscious and planned effort to create an atmosphere of learning and the learning process so that students actively develop their potential for have religious spiritual strength, self-control, personality, intelligence, noble character, and skills needed by him, society, nation and state.
Improving the quality of education is determined by the readiness of human resources involved in the education process. Teachers are one of the determining factors for the high and low quality of educational outcomes that have a strategic position, so every effort to improve the quality of education needs to pay great attention to increasing teachers both in terms of number and performance [1].

Researchers limit the problem to the study of the effect of work motivation and professional competence of teachers on the performance of junior high school teachers in Kedaton Subdistrict Observation Raya Ogan Komering Ulu Regency. In this study, not all factors related to motivation will be discussed, because the independent variables studied were only work motivation and professional competence of junior high school teachers. while the dependent variable in this study is the performance of junior high school teachers.

The formulations of the problems that can be taken in this study are: 1 . Is there an effect of teacher work motivation on the performance of junior high school teachers in Kedaton Peninandang Raya Subdistrict, Ogan Komering Ulu Regency? 2. Is there an effect of professional competence on the 
performance of junior high school teachers in Kedaton Peninajian Raya Subdistrict, Ogan Komering Ulu Regency? 3. Is there an effect of teacher work motivation and professional competence together on the performance of junior high school teachers in Kedaton Peninandang Raya Subdistrict, Ogan Komering Ulu Regency?

The purpose of this study was to determine 1 . the effect of teacher work motivation on the performance of junior high school teachers in the District of Kedaton Peninandang Raya, Ogan Komering Ulu Regency, 2. the effect of professional competence on the performance of junior high school teachers in Kedaton Peninandang Raya Subdistrict, Ogan Komering Ulu Regency and 3. the influence of teacher work motivation and professional competence jointly on the performance of junior high school teachers in Kedaton Peninandang Raya Subdistrict, Ogan Komering Ulu Regency.

The hypothesis is a temporary answer to the research problem, until it is proven through the collected data. The hypothesis in this case serves as a guide that allows us to get the real answer [2]. Based on the study of the theory and frame of mind, a hypothesis can be used as a temporary answer to the problems under study, namely:

a. Alternative Hypothesis (Ha)

There is an effect of work motivation on the performance of junior high school teachers in the District of Kedaton Peninandang Raya, Ogan Komering Ulu Regency, 2. There is an effect of teacher professional competence on the performance of junior high school teachers in Kedaton Peninandang Raya Subdistrict, Ogan Komering Ulu Regency, 3. There is an influence of work motivation and teacher professional competence jointly on the performance of junior high school teachers in the District of Kedaton Peninandang Raya, Ogan Komering Ulu Regency.

b. Hypothesis Zero (Ho)

Work motivation does not have a significant effect on the performance of junior high school teachers in Kedaton Peninajian Raya Subdistrict, Ogan Komering Ulu Regency, 2. Teacher professional competence does not have a significant effect on the performance of junior high school teachers in Kedaton Peninajian Raya Subdistrict, Ogan Komering Ulu Regency, 3. Work motivation and professional competence teachers together do not have a significant effect on the performance of junior high school teachers in Kedaton Peninajian Raya Subdistrict, Ogan Komering Ulu Regency.

\section{Work motivation}

Etymologically, the term motivation comes from the Latin movere which means to move '(to move) (Winardi 2011: 24). Motivation means encouraging, directing and perpetuating a behavior. The term motivation comes from the word motive which can also be interpreted as an impetus or strength that is contained within an individual, which causes the individual to act and act.

A person who has a big and strong motivation will do his job seriously responsibly in order to get satisfactory results. A teacher who has high work motivation will produce quality, civilized, faithful students or human resources who are also responsible for themselves and others.

Motivation can come from factors from within the individual himself, including a strong urge from within who wants to do something seriously in order to achieve the desired goals, the spirit from within himself to work in a disciplined and timely manner, External factors include support from other people both from within the family and colleagues and the work environment.

The indicator of the teacher work motivation variable studied is intrinsic motivation including work performance and work morale, extrinsic motivation includes relationships with peers and the work environment.

\section{Teacher Professional Competence}

Apart from having high work motivation, educators must also have the competence or ability to carry out work in accordance with their expertise or scientific field. Competence is a specification of knowledge, skills and attitudes that a person has and their application in work in accordance with the performance standards required by the field [3].

Teacher competence is a set of knowledge, skills and behaviors that must be possessed by teachers (PP 74 of 2008). Teacher professionalism comes from the word profession, which means that a field of work to be occupied by a profession is also interpreted as a tool that requires expertise, proficiency or skills that meet certain quality standards and requires professional education (Law No. 14 of 2005 on teachers and lecturers). Professionalism is a skill in certain positions that require specific competencies (knowledge, attitudes and skills) obtained from intensive academic education [4].

In the Law of the Republic of Indonesia No.14 / 2005 concerning Teachers and Lecturers and Government Regulation No. 14/2005 on National Education Standards (SNP), a teacher must have four basic competencies, namely personality competence, pedagogical competence, professional competence, and social competence, where these four competencies are integrated into teacher performance.

From the understanding of competence and professionalism above, it can be concluded that the professional competence of teachers is the ability, skills and behavior that a teacher must have as an educator who has a big responsibility in educating the nation's 
future. Competence according to Suparlan "professional competence is the ability that teachers must have in planning and implementing the learning process". The teacher has a task, one of which is to provide direction to students in achieving learning goals [5].

The indicators of professional competence of teachers studied include mastery of competency standards and basic competencies of the subjects being handled. Mastering material, structure, concepts, and scientific thought patterns that support the subject being taught. Developing creative learning materials.

\section{Teacher Performance}

Teacher performance is the result of a teacher's work both in quality and quantity which is shown in his appearance, actions, and work performance as an accumulation of knowledge, skills, values, abilities, motivation, opportunities and attitudes he has had in the process of teaching, educating, guiding, train and direct students towards mental-spiritual and physicalpsychological maturity [6]. Suharsaputra states that teacher performance is a major component in the education or learning process in schools [7].

Assessment indicators on teacher performance variables carried out on classroom learning, namely (a) Planning Learning Activities Program (Syllabus Design and RPP), (b) Implementation of Learning Activities (class management, use of media and learning resources, use of learning methods), and (c) ) Learning assessment.

\section{METHODS}

The method used in this research is quantitative research methods. Quantitative research methods can be defined as a research method based on the philosophy of positivism used to research a particular population or sample, data collection using a questionnaire or questionnaire, and documentation, and data analysis using descriptive data analysis, t-test analysis, F-test analysis. , and a statistical coefficient of determination with the aim of testing the predetermined hypothesis [8].

This research is included in correlational research. Correlational research is research that will look at the influence or relationship between a variable or several variables with other variables [9]. This research is included in correlation research which according to Emzir in correlational research each variable must be expressed in numerical form, which can be calculated. The calculations in this study use the help of the SPSS version 21.0 data processing application [10].

The population in this study were 100 people and with a sample of 50 junior high school teachers in the Kedaton Peninandang Raya district. Which is taken randomly or simple random sampling. The variables in this study consisted of three variables, namely work motivation (X1), teacher professional competence (X2) and teacher performance (Y). The questionnaire instrument was tested on 20 junior high school teachers, after being declared validation by three competent validators [11]. After being valid and reliable, the questionnaire instrument was continued with the research sample [12].

\section{RESULTS AND DISCUSSION}

One of the conditions that must be met in the regression analysis is that the data and regression models must be normally distributed.

Table 1. Output Normality Test Using Kolmogorov-Smirnov

\begin{tabular}{lcccccc}
\hline \multicolumn{1}{c}{ Tests of Normality } \\
\hline \multicolumn{1}{c}{ Kolmogorov-Smirnov } \\
& Statistic & Df & Sig. & Statistic & df & Sig. \\
Motivation &, 124 & 50 &, 053 &, 963 & 50 &, 120 \\
$\begin{array}{l}\text { Professional } \\
\text { Competence }\end{array}$ &, 103 & 50 &, $200^{*}$ &, 951 & 50 &, 036 \\
$\begin{array}{l}\text { Teacher } \\
\text { Performance }\end{array}$ &, 123 & 50 &, 057 &, 968 & 50 &, 191
\end{tabular}

Performance

*. This is a lower bound of the true significance.

a. Lilliefors Significance Correction

From table 1, the significance value of the teacher work motivation variable is 0.053 , the teacher professional competence variable is 0.200 and the teacher performance variable significance value is 0.057 where the three variables are $>0.05$, which means that $\mathrm{Ha}$ is accepted or the data from each variable is normally distributed.

In addition to using the Kolmogorov-Smirnof normality test, the analysis prerequisite test can also be used by using the linearity test of each variable.

Table 2. Output Linearity Test Work Motivation Against Teacher Performance

ANOVA Table

\begin{tabular}{|c|c|c|c|c|c|c|c|}
\hline & & & $\begin{array}{c}\text { Sum of } \\
\text { Squares }\end{array}$ & $\overline{\mathrm{Df}}$ & $\begin{array}{l}\text { Mean } \\
\text { Square }\end{array}$ & $\mathrm{F}$ & Sig. \\
\hline \multirow{6}{*}{$\begin{array}{l}\text { Perf } \\
\text { orm } \\
\text { ance } \\
* \\
\text { Mot } \\
\text { ivati } \\
\text { on }\end{array}$} & \multirow{4}{*}{$\begin{array}{l}\text { Bet } \\
\text { wee } \\
\mathrm{n} \\
\text { Gro } \\
\text { ups }\end{array}$} & $\begin{array}{l}\text { (Comb } \\
\text { ined) }\end{array}$ & 3847,820 & 31 & 124,123 & 9,952 & ,000 \\
\hline & & $\begin{array}{l}\text { Linear } \\
\text { ity }\end{array}$ & 3193,233 & 1 & $\begin{array}{r}3193,23 \\
3\end{array}$ & 256,028 & ,000 \\
\hline & & $\begin{array}{l}\text { Deviat } \\
\text { ion }\end{array}$ & 654,587 & 30 & 21,820 & 1,749 & , 107 \\
\hline & & $\begin{array}{l}\text { from } \\
\text { Linear } \\
\text { ity }\end{array}$ & & & & & \\
\hline & \multicolumn{2}{|c|}{$\begin{array}{l}\text { Within } \\
\text { Groups }\end{array}$} & 224,500 & 18 & 12,472 & & \\
\hline & \multicolumn{2}{|c|}{ Total } & 4072,320 & 49 & & & \\
\hline
\end{tabular}

Source: Primary data processed, 2020 
Based on table 2 the output of the linearity test results above, the significance value on the line Deviation from linearity is $0.107>$ á (á $=0.05)$, so the relationship between work motivation and performance variables is linear.

Table 3. Output Linearity Test Teacher Competence Against Teacher Performance

ANOVA Table

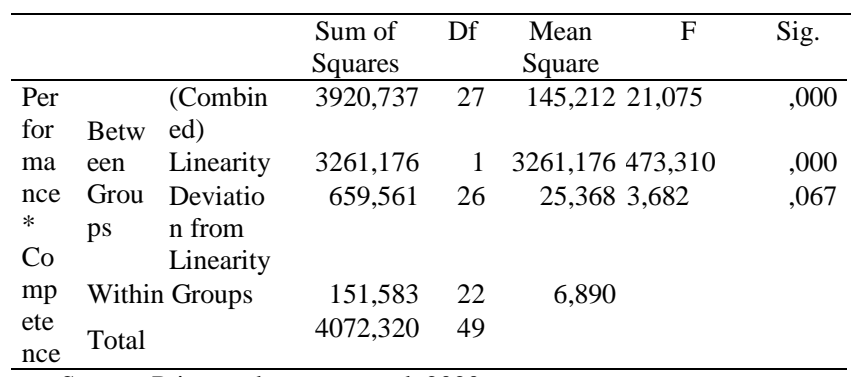

Source: Primary data processed, 2020

Based on table 3 the output of the linearity test results above, the significance value on the line Deviation from linearity is $0.067>$ á (á $=0.05)$, so the relationship between the variable teacher professional competence and performance is linear.

\section{Work Motivation (X1)}

Based on the results of the descriptive analysis, the percentage of the teacher work motivation variable as a whole shows that the variable of work motivation for junior high school teachers in Kedaton sub-district, Observation, Ogan regency, Komering ulu, is in the high category with a percentage of $60 \%$.

Based on calculations and descriptive analysis, the percentage of teacher work motivation variables per indicator shows that for the indicator of morale in the high category with a percentage of $100 \%$, it means that the teacher already has high morale, which is reflected in time discipline and enthusiasm in carrying out work.

For indicators of encouragement and efforts to affiliate, it is in the very high category with a percentage of $100 \%$. This is reflected in their high desire to form partnerships with school principals, peers and to establish good relationships with all existing school members.

Support for the work environment of junior high school teachers in Kedaton sub-district, Ogan observation highway, Ogan Komering Ulu district can be categorized as high. It can be seen from the number of respondents who $100 \%$ dominate in the high criteria. It is said, this high is because most of the teachers already have support from the school environment, especially learning facilities and a conducive environment.

\section{Professional Competence}

Based on the results of the descriptive analysis of the percentage of the variable of professional competence of junior high school teachers in Kedaton Subdistrict Observation Raya, Ogan Komering Ulu Regency as a whole shows that the professional competence of teachers is in the high category with a percentage of $74 \%$.

Based on the calculation and descriptive analysis, the percentage of teacher professional competence variables per indicator shows that for the indicator of the ability to master competency standards and learning competencies in the high category with a percentage of $100 \%$, it means that junior high school teachers in Kedaton sub-district Observation Raya Ogan Komering Ulu district already have an understanding and mastery of the structure, basic concepts, mindsets, competency standards, basic competencies to the goals of learning [13].

The indicator of mastery of subject matter in the high category with a percentage of $100 \%$ means that the teacher already has an understanding of the concepts and structures of learning material and mastery of learning material [14].

The percentage of learning material development indicators is in the high category because $100 \%$ of respondents have the ability to process learning material creatively according to the level of development of students [19].

\section{Teacher Performance (Y)}

Based on the results of the descriptive analysis of the percentage of the performance variables of junior high school teachers in Kedaton Subdistrict, Ogan Observation District, Ogan Komering Ulu as a whole shows that teacher performance is in the high category with a percentage of $66 \%$.

Based on calculations and descriptive analysis, the percentage of teacher performance variables per indicator shows that the indicators for making learning plans are high with the domination of respondents by $90.91 \%$. It is said to be high because most of the junior high school teachers in Kedaton sub-district, Ogan Komering Ulu district, have prepared themselves in terms of lesson planning starting from making lesson plans, providing learning media to preparing as a whole according to the needs of learning [15].

For indicators of implementing the results of the implementation of learning from junior high school teachers in Kedaton sub-district, the observation on the highway of Ogan Komering Ulu district can be categorized as high. This can be seen from the number of respondents who dominate into high criteria with a percentage of $100 \%$. It is said that this is high because most of the junior high school teachers in the Kedaton sub-district surveying Ogan Komering Ulu district have 
been able to carry out the learning carried out by the teacher as long as the learning process is going well [16].

The indicator of the implementation of the learning evaluation of junior high school teachers in the Kedaton sub-district, Ogan observation highway, Ogan Komering Ulu can be categorized as high with a percentage of $71.4 \%$. This can be seen from the number of respondents who dominate into high criteria. It is said that this is high because most of the teachers have been able to carry out evaluation of the learning carried out by the teacher during the process until the end of the learning process.

Effect of Work Motivation (X1), on Teacher Performance (Y)

Table 4. Output Results of Multiple Linear Correlation Analysis

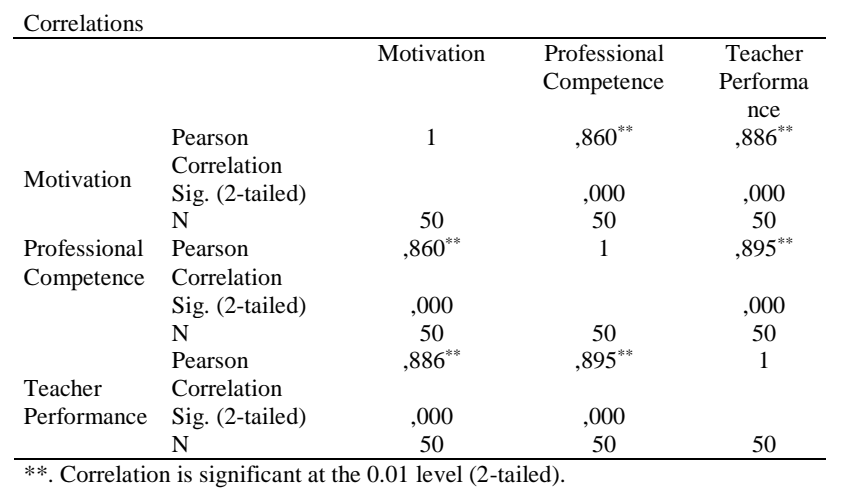

The calculation of the value of the correlation coefficient from table 4 is 0.886 including the strong positive category indicating that there is a significant influence between work motivation on the performance of junior high school teachers in Kedaton Penininjau Raya District, Ogan Komering Ulu Regency.

Tabel 5. Output Determination Test Results Summary The Effect of Work Motivation on Teacher Performance

Model Summary

\begin{tabular}{ccccc}
\hline Model & $\mathrm{R}$ & $\begin{array}{c}\mathrm{R} \\
\text { Square }\end{array}$ & $\begin{array}{c}\text { Adjusted R } \\
\text { Square }\end{array}$ & $\begin{array}{c}\text { Std. Error of } \\
\text { the Estimate }\end{array}$ \\
1 &, $886^{\mathrm{a}}$ &, 784 &, 780 & 4,280 \\
\hline
\end{tabular}

a. Predictors: (Constant), Motivation

Source: Primary data processed, 2020

And based on the calculation and analysis of the partial determination test in Table 5, it shows that the effect of teacher work motivation partially on teacher performance is $78.4 \%$ while $21.6 \%$ is influenced by other factors or variables and is not examined in this study [17].
The Effect of Teacher Professional Competence on Teacher Performance

Analysis of the correlation coefficient value is from table 4 above of 0.895 , including the strong positive category. This indicates that there is a significant influence between teacher professional competence on teacher performance.

Table 6. Output Results of Determination Test Summary the Effect of Teacher Professional Competence on Teacher Performance

Model Summary

$\begin{array}{ccccc}\text { Model } & \text { R } & \text { R Square } & \begin{array}{c}\text { Adjusted R } \\ \text { Square }\end{array} & \begin{array}{c}\text { Std. Error of } \\ \text { the Estimate }\end{array} \\ 1 & , 895^{\mathrm{a}} & , 801 & , 797 & 4,111\end{array}$

a. Predictors: (Constant), Professional Competence

Source: Primary data processed, 2020

Based on the calculation and analysis of the partial determination test from table 6 , it shows that the effect of partially teacher professional competence on teacher performance is $80.1 \%$ while $19.9 \%$ is influenced by other factors or variables and is not examined in this study.

The effect of teacher work motivation and teacher professional competence on teacher performance

The regression analysis used in this study is multiple linear regression with three predictors, namely teacher professional competence (X1), work motivation (X2), and teacher performance (Y) as the dependent variable.

Table 7. Results of Multiple Linear Regression Analysis

Coefficients

\begin{tabular}{|c|c|c|c|c|c|c|}
\hline & \multirow[t]{2}{*}{ Model } & \multicolumn{2}{|c|}{$\begin{array}{c}\text { Unstandardized } \\
\text { Coefficients }\end{array}$} & \multirow{2}{*}{$\begin{array}{c}\text { Standardized } \\
\text { Coefficients } \\
\text { Beta }\end{array}$} & \multirow[t]{2}{*}{$\mathrm{t}$} & \multirow[t]{2}{*}{ Sig. } \\
\hline & & B & Std. Error & & & \\
\hline \multirow{3}{*}{1} & (Constant) & 19,472 & 4,320 & & $\begin{array}{r}4,50 \\
8\end{array}$ &, 000 \\
\hline & Motivation & ,294 & ,072 & , 445 & $\begin{array}{r}4,05 \\
5\end{array}$ &, 000 \\
\hline & $\begin{array}{l}\text { Professional } \\
\text { Competence }\end{array}$ & ,510 & , 109 &, 512 & $\begin{array}{r}4,66 \\
5\end{array}$ &, 000 \\
\hline
\end{tabular}

a. Dependent Variable: Teacher Performance

Source: Primary data processed, 2020

Based on table 4 above, it is found that the constant value of the regression equation $a$ is 19.472 and the coefficient value of the independent variable $b 1$ is 0.294 and $b 2$ is 0.510 , then the regression equation is obtained as follows:

$$
\mathrm{Y}=19,472+0.294 \mathrm{X} 1+0.510 \mathrm{X} 2 \text {. }
$$

Then the coefficient value of work motivation (X1) is 0.294 , meaning that if work motivation 
increases by one unit, the regression coefficient value of teacher performance will increase by 0.294 with the assumption that $\mathrm{X} 2$ is fixed.

The regression value of teacher professional competence $(\mathrm{X} 2)$ is 0.510 , meaning that if the competence (X2) increases by one unit, the teacher's performance will increase by 0.510 assuming constant work motivation.

Based on the simultaneous test (Test F), it was found that the significant value was 0.00 less than 0.05 so that Ho was rejected, meaning that there was an effect of work motivation and teacher professional competence on the performance of junior high school teachers in the Kedaton Peninandang Raya district, Ogan Komering Ulu Regency. And the calculation of the value of the partial determination coefficient was obtained at 0.852 . This value means that the effect of teacher work motivation and teacher professional competence on teacher performance simultaneously is $85.2 \%$ and is categorized as high, while $14.8 \%$ is influenced by other factors or variables and is not examined in this study [18].

\section{CONCLUSION}

Based on the results of the research that has been done, conclusions can be drawn that : (1). There is a significant effect of work motivation on the performance of junior high school teachers in Kedaton Peninajian Raya Subdistrict, Ogan Komering Ulu Regency, (2). There is a significant effect of teacher professional competence on the performance of junior high school teachers in Kedaton Peninajian Raya District, Ogan Komering Ulu Regency. (3). There is a significant effect of work motivation and professional competence of teachers on the performance of junior high school teachers in Kedaton Peninandang Raya District, Ogan Komering Ulu Regency. komering ulu,

From the results of the research conclusions above, it is suggested that teachers should increase work motivation so that the resulting performance will be maximized. Principals, should pay more attention and provide motivation to work so that the resulting employee performance will be maximized. In future researchers, it is hoped that they can examine other factors that also affect teacher performance in addition to work motivation and teacher professional competence so that other factors that contribute to teacher performance can be identified.

\section{REFERENCES}

[1] Permendikbud no 22 tahun 2016. Tentang Standar Proses Pendidikan Dasar dan Menengah. Jakarta: Depdiknas.

[2] Undang-Undang Sistem Nasional Pendidikan No. 20 Tahun 2003. Jakarta: Depdiknas.
[3] Zulfiter, Z., Fitria, H., \&Nurkhalis, N. (2020). Pengaruh Gaya Kepemimpinan Kepala Sekolah dan Motivasi Kerja Terhadap Kinerja Guru. ISEJ: Indonesian Science Education Journal, 1(3), 269-277.

[4] Arikunto, Suharsimi 2010. Prosedur Penelitian Suatu Pendekatan Praktik. Jakarta: Rineka Cipta.

[5] Winardi. 2011. Motivasi dan Permotivasian Dalam Manajemen. Jakarta: Raja.

[6] Dirjen Dekdismen. 2004. Kamus Besar Bahasa Indonesia. Jakarta : Balai Pustaka.

[7] Peraturan Pemerintah Nomor. 74. 2008. Tentang Guru. Jakarta: Depdiknas.

[8] Fathurrochman, I., Hariani, D., Hamengkubuwono, H., Arsil, A., Muhammad, A., \& Ristianti, D. H. (2020). The Development of Student Academic Administration Services in Higher Education. International Journal of Psychosocial Rehabilitation, 24(8), 4764-4771.

[9] Undang-Undang Republik Indonesia No. 14. 2005 Tentang Guru dan Dosen. Jakarta: Depdiknas.

[10] Ristianti, D. H., Putrajaya, G., \& Fathurrochman, I. (2020). Organizational behavior management through group counseling discussions as a radicalism preventive effort. Jurnal Konseling dan Pendidikan, 8(1), 23-31.

[11] Kristiawan, M., \& Rahmat, N. (2018). Peningkatan Profesionalisme Guru Melalui Inovasi Pembelajaran. Jurnal Iqra': Kajian Ilmu Pendidikan, 3(2), 373-390.

[12] Peraturan pemerintah Nomor 14. 2005. Tentang Standar Nasional Pendidikan (SNP). Jakart: Depdiknas.

[13] Suparlan. 2008. Menjadi Guru yang Efektif. Yogyakarta: Hikayat.

[14] Hayati, R., Arafat, Y., \& Puspita Sari. A. (2020). Pengaruh komitmen Organisasi dan Motivasi Kerja Terhadap Kinerja Guru. Jurnal Manajemen, Kepemimpinan, dan Supervisi Pendidikan. 5(2). pp. 100-111.

[15] Suharsaputra. (2018). Supervisi Pendidikan. Bandung: PT Refika Aditama.

[16] Sugiyono. (2018). Metode Penelitian Kuantitatif. Bandung: Alfabeta.

[17] Riyanto. (2010). Metodologi Penelitian Pendidikan. Surabaya: SIC

[18] Emzir. (2015). Metodologi Penelitian 
Pendidikan Kuantitatif dan Kualitatif. Jakarta: Raja Grafindo Persada

[19] I. Fathurrochman, S. Danim, S. A. Ab, and N. Kurniah, "The School Principals' Role in
Education Management at the Regional Level : An Analysis of Educational Policy in the Industrial Revolution 4 . 0," no. 532, pp. $237-$ 242, 2021. 